Web Jurnal:

http://ejournal.kemenperin.go.id/jli

\title{
Pemanfaatan katekin ekstrak gambir (Uncaria gambir Roxb) sebagai pengawet alami terhadap karakteristik mie basah
}

\section{Utilization of catechin extract of gambier (Uncaria gambir Roxb) as a natural preservative on the characteristics of wet noodles}

K Kamsina*, F Firdausni, dan S Silfia

Balai Riset dan Standardisasi Industri Padang

J1. Raya LIK No. 23, Ulu Gadut, Padang, Indonesia

* e-mail: kamsinaina@gmail.com

\begin{tabular}{l}
\hline INFO ARTIKEL \\
\hline Sejarah artikel: \\
Diterima: \\
4 Oktober 2020 \\
Direvisi: \\
4 Desember 2020 \\
Diterbitkan: \\
28 Desember 2020
\end{tabular}

\section{Kata kunci:}

katekin;

ekstrak gambir; pengawet pangan; mie basah

Keywords:

katechin;

gambir extract; food preservatives, wet noodles

\begin{abstract}
ABSTRAK
Ekstrak gambir merupakan ekstrak dari sari getah yang diekstraksi dari daun tanaman gambir dan mengandung senyawa antioksidan yang berfungsi sebagai pengawet pangan. Guna meningkatkan ketahanan simpan pangan dan meminimalisir penggunaan pengawet sintetis dilakukan penelitian ini dengan tujuan mengetahui pengaruh pemberian konsentrasi ekstrak gambir terhadap nilai gizi dan ketahanan simpan mie basah. Penelitian dilakukan dengan metoda Rancangan Acak Lengkap (RAL) dengan persentase ekstrak gambir yaitu $0 \%$ (kontrol), $0,1 \%, 0,2 \%, 0,3 \%$ dan $0,4 \%$ dengan 5 kali ulangan. Peningkatan penggunaan ekstrak gambir menyebabkan peningkatan nilai kadar air menjadi $34,706 \%$, kadar abu $0,044 \%$, antioksidan $18,820 \%$ dan total fenol $84 \%$. Hasil perlakuan optimal didapatkan pada perlakuan $0,2 \%$ untuk uji organoleptik warna, rasa, aroma, dan tekstur disukai dengan nilai berturut-turut 3,$50 ; 4,00 ; 4,13$ dan 4,24. Sedangkan untuk ketahanan simpan mie basah, sampai hari ke-4 cemaran mikroba (angka lempeng total) mengandung $9,8 \times 10^{5}$ koloni/g dan memenuhi standard SNI 2987:2015 tentang mie basah.
\end{abstract}




\section{Pendahuluan}

Pola konsumsi dengan makanan siap saji sangat mempengaruhi makanan masyarakat Indonesia. Makanan jajanan yang bersifat instan, menarik, dan harga terjangkau menjadi pilihan yang banyak disukai masyarakat. Indonesia memiliki masyarakat yang gemar mengkonsumsi mie. Mie sudah menjadi seperti makanan kedua setelah nasi karena kandungan karbohidrat yang tinggi dan dapat digunakan sebagai bahan pangan alternatif karena kandungan gizi mie tidak kalah baiknya dengan beras, dimana bahan baku utamanya adalah tepung terigu yang berasal dari biji gandum. Fungsi dari tepung terigu yaitu sebagai pembentuk sifat kenyal gluten, sumber protein, serta bahan pembentuk struktur (Oktiarni et al., 2012).

Produk mie yang dikenal oleh masyarakat di Indonesia salah satunya adalah mie basah. Di Indonesia, mie basah dikenal sebagai mie pangsit, mie bakso atau mie. Mie basah adalah jenis mie yang mengalami proses perebusan dengan kadar air mie basah matang mencapai $52 \%$, sehingga daya tahan atau keawetannya cukup singkat. Masa simpan mie basah yang cukup singkat menyebabkan banyak usaha untuk memperpanjang masa simpannya dengan menambahkan pengawet. Namun sayangnya pada proses pembuatan mie ini sering produsen menggunakan pengawet yang tidak diperbolehkan oleh pemerintah dalam penggunaaannya, seperti formalin dan boraks (Ayu et al., 2018; Male et al., 2017; Oktiarni et al., 2013; Tumbel, 2010).

Penggunaan pengawet sintetis dapat membahayakan kesehatan, sehingga sangat diperlukan alternative pengawet makanan yang lebih aman dan sehat, salah satunya dengan menggunakan bahan yang alami. Jenis bahan alami seperti ekstrak gambir memiliki aktivitas antimikroba yaitu senyawa yang dapat menghambat pertumbuhan mikroba sehingga makanan menjadi awet (Kamsina and Firdausni, 2018).

Gambir merupakan sejenis getah berwarna coklat kehitaman yang dikeringkan, berasal dari ekstrak remasan daun dan ranting tumbuhan Uncaria gambir Roxb. Gambir memiliki dua komponen utama yaitu katekin dan asam katekutannat yang mempunyai banyak manfaat. Gambir mengandung polifenol atau katekin yang bekerja sebagai antioksidan dan antimikroba. Katekin adalah kelompok metabolik sekunder yang diproduksi secara alami oleh tumbuhan merupakan senyawa flavonoid yang termasuk dalam golongan polifenol. Antioksidan memiliki kemampuan untuk menangkap radikal bebas dari makanan dengan menyumbangkan atom hidrogen (Melia et al., 2015).

Gambir mengandung berbagai senyawa fungsional, antara lain zat samak (22\%), kuersetin (2-4\%), fluoresein gambir (1-3\%), pyrocatechol $(20-30 \%)$, catechu merah (3-5\%), lendir, lemak, lilin (1-2\%), dan polifenol. Senyawa polifenol utama dalam gambir adalah katekin sekitar 50\%, dalam gambir yang terutama adalah katekin (50\%) (Rahmawati, Noveri; Wachyuni, 2013).

Ekstrak gambir merupakan sediaan kental yang diperoleh dengan mengekstraksi senyawa aktif dari gambir menggunakan pelarut yang sesuai. Pada proses ini semua atau hampir semua pelarutnya diuapkan sehingga terbentuk massa serbuk (Anggraini et al., 2011).

Penelitian-penelitian yang berkaitan dengan ekstrak hayati dan nabati sebagai pengawet alami telah banyak diteliti diantaranya oleh (Enjelina et al., 2019) mengenai pemanfaatan kulit buah naga merah untuk mie basah, (Ayu et al., 2018) menggunakan jus lengkuas sebagai pengawet mie basah, (Oktiarni et al., 2013) pemanfaatan ekstrak bunga kembang sepatu sebagai pewarna dan pengawet pada mie basah, (Li et al., 2014) menggunakan beberapa pengawet alami pada tepung pasta dan mie, (Sari et al., 2019) pengaruh fisik ikan lele asap yang diintoduksi dengan gambir serta (Firdaus et al., 2015) menggunakan ekstrak abu sabut kelapa sebagai pengenyal dan pengawet pada mie basah.

Berdasarkan permasalahan-permasalahan dan penelitian-penelitian tersebut, maka dilakukanlah penelitian mengenai pemanfaatan katekin ekstrak gambir (Uncaria gambir Roxb) untuk bahan pengawet alami mie basah. Tujuan dari penelitian ini adalah untuk mendapatkan konsentrasi katekin ekstrak gambir yang optimal sebagai pengawet alami pada mie basah.

\section{Metode}

Bahan utama yang diperlukan adalah gambir, ethanol $70 \%$, aquadest, ethanol $96 \%$, bahan-bahan untuk mie serta bahan untuk pengujian. Peralatan yang digunakan adalah peralatan untuk membuat ekstrak gambir serta peralatan pengujian.

Rancangan penelitian memakai rancangan acak lengkap (RAL) dengan 5 (lima) kali ulangan. Perlakuan katekin ekstrak gambir yang digunakan sebagai pengawet alami pada mie basah adalah variasi kosentrasi katekin sebagai berikut: $0 \%$ (kontrol), 0,1\%, 0,2\%, 0,3\% dan 0,4\%. Masing-masing perlakuan dilakukan dengan 5 kali ulangan, data yang diperoleh diolah secara statistik dengan uji lanjutan DNMRT pada taraf nyata 5\%. Produk mie pangsit yang telah diberi perlakuan ekstrak gambir sebagai pengawet dikemas dengan menggunakan plastik Polypropilen dengan ketebalan $0,1 \mathrm{~cm}$ serta disimpan pada suhu kamar.

Proses pembuatan katekin dilakukan sebagai berikut; Gambir sebanyak 2,5 kg yang telah dihaluskan dimasukkan dalam wadah stainless steel, ditambahkan akuades sebanyak 10 liter yang telah dipanaskan, didiamkan selama 24 jam, bahan dicuci berulang-ulang dengan air dingin, dan diendapkan, Setelah itu endapan dikeringkan (Kamsina, 2018). Endapan yang telah dikeringkan ini nantinya yang digunakan sebagai pengawet alami pada mie basah.

Pengujian yang dilakukan terhadap ekstrak gambir adalah kadar katekin dan kadar tanin, kadar air dan kadar abu. sedangkan sebagai pengawet pada mie pangsit meliputi kadar air (metode oven), kadar abu dengan metode gravimetri (Badan Standardisasi Nasional, 2000), sementara pengujian antioksidan ditentukan dengan metode $\mathrm{Xu}$ dan Chang (2007) serta total fenol diuji dengan metode Folin Ciocalteu menggunakan asam galat sebagai standar (Pujimulyani et al., 2010).

Ketahanan simpan mengacu pada parameter angka lempeng total. Uji organoleptik dilakukan oleh panelis berdasarkan tingkat kesukaan, meliputi rasa, warna, 
aroma dan terhadap mie basah dengan skala hedonik sangat suka (5), suka (4), biasa (3), kurang suka (2) dan tidak suka (1).

\section{Hasil dan pembahasan \\ 3.1. Analisis kimia bahan baku}

Analisis terhadap bahan baku gambir didapatkan kadar air 19,1\%, kadar abu 0,7\%, kadar katekin 89,05\%, dan kadar tanin 18,97\%. Semua hasil analisis katekin gambir memenuhi SNI 01-3391:2000 (Gambir) (Badan Standardisasi Nasional, 2000).

\subsection{Hasil analisis kimia produk \\ 3.2.1. Kadar air dan kadar abu}

Hasil analisis dari ekstrak gambir menunjukkan bahwa semua perlakuan berpengaruh terhadap kadar air dan kadar abu dari produk mie basah. Adapun hasilnya dapat dilihat pada Gambar 1. Dari hasil tersebut dapat dilihat bahwa kadar air tertinggi didapatkan pada perlakuan pemberian katekin ekstrak gambir $0,4 \%$ yaitu $34,71 \%$ dan kadar abu sebesar 1,443\% sedangkan kadar air terendah didapatkan pada konsentrasi katekin $0 \%$ (kontrol) senilai 29,10\% dan kadar abu 1,440\% serta berbeda dengan perlakuan lainnya.

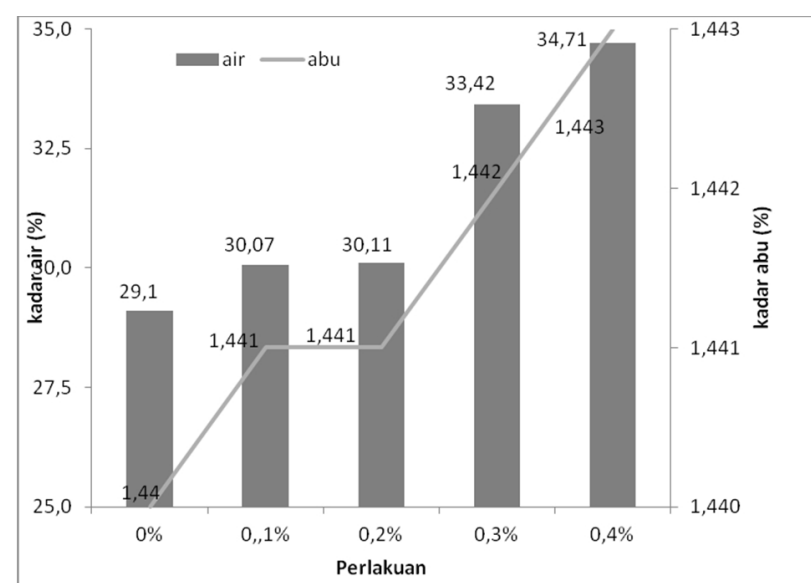

Gambar 1. Hasil analisis kadar air dan kadar abu mie basah dengan pengawet ekstrak gambir

Tingginya kadar air pada perlakuan konsentrasi 0,4\% katekin ekstrak gambir seperti terlihat pada histogram menunjukkan bahwa semakin banyak jumlah katekin gambir yang ditambahkan ke dalam formula, maka semakin tinggi pula kadar airnya. Hal ini disebabkan katekin gambir memiliki sifat lebih mudah larut dalam air dan bersifat higroskopis (Kailaku et al., 2005).

Penetapan kadar air (moisture) adalah bagian/contoh yang hilang jika dipanaskan pada kondisi uji tertentu. Kadar air dalam bahan makanan sangat mempengaruhi kualitas dan daya simpan dari pangan tersebut. Oleh karena itu, penentuan kadar air dari suatu bahan pangan sangat penting agar dalam proses pengolahan maupun pendistribusian mendapat penanganan yang tepat. Penentuan kadar air dalam makanan dapat dilakukan dengan dengan beberapa metode, yaitu metode pengeringan (dengan oven biasa), metode destilasi, metode kimia, dan metode khusus (Sundari et al., 2015).
Kandungan air dalam bahan makanan mempengaruhi daya tahan bahan makanan terhadap serangan mikroba yang dinyatakan dengan $a_{w}$, yaitu jumlah air bebas yang dapat digunakan oleh mikroorganisma untuk pertumbuhannya. Hubungan antara $A_{w}$ dengan kandungan air per gram suatu bahan makanan disebut isoterm sorpsi air. Pada bahan pangan isoterm sorpsi air dapat menggambarkan kandungan air yang dimiliki bahan tersebut sebagai keadaan kelembaban relatif ruang tempat penyimpanan (Herawati, 2008).

Hasil analisis menunjukkan kadar air produk mie basah berkisar antara 29,098\% - 34,706\%. Berdasarkan SNI 2987:2015 mengenai mie basah, nilai kadar air yang dipersyaratkan adalah maksimum 35\%. Sehingga dapat disimpulkan bahwa untuk semua perlakuan kadar airnya memenuhi persyaratan (Badan Standardisasi Nasional, 2015).

Kadar abu merupakan campuran dari komponen anorganik atau mineral yang terdapat pada suatu bahan makanan olahan. Bahan pangan terdiri dari $96 \%$ bahan organik dan air, sedangkan sisa nya merupakan unsurunsur mineral yang dikenal sebagai zat organik atau kadar abu. Kandungan abu bahan pangan dan komposisinya tergantung pada jenis bahan dan cara pengabuannya dan dapat menunjukan total mineral dalam suatu bahan pangan. Bahan-bahan organik dalam proses pembakaran akan terbakar tetapi komponen anorganiknya tidak, karena itulah disebut sebagai kadar abu (Sundari et al., 2015).

Kadar abu cenderung meningkat dengan meningkatnya konsentrasi ekstrak gambir yang diberikan pada mie pangsit. Kenaikan kadar abu ini berbanding lurus dengan hasil kadar air yang didapatkan. Hal ini dapat disebabkan oleh banyaknya pemakaian ekstrak gambir yang mengandung bahan-bahan anorganik yang berasal dari bahan bakunya sendiri (Kailaku et al., 2005).

Penetapan kadar abu bertujuan untuk memberikan gambaran tentang kandungan mineral internal dan eksternal yang berasal dari proses awal sampai terbentuknya ekstrak. Kadar abu tidak boleh terlalu tinggi karena di dalam kadar abu terdapat mineralmineral yang dapat menyebabkan pengendapan di dalam ginjal sehingga dapat mengganggu kesehatan (Aditya and Ariyanti, 2016; Setyaningsih et al., 2014).

Nilai kadar abu yang didapatkan pada penelitian ini berkisar antara 0,0440\% - 0,0443\%, Nilai kadar abu untuk semua perlakuan memenuhi SNI 2987:2015 mengenai mie basah yaitu maksimum $0,05 \%$ (Badan Standardisasi Nasional, 2015).

\subsubsection{Antioksidan dan total fenol}

Hasil analisis dari pemanfaatan ekstrak gambir sebagai pengawet alami pada mie basah, setelah dilakukan analisis secara statistik menunjukkan bahwa semua perlakuan berpengaruh nyata terhadap antioksidan dan total fenol pada mie basah seperti terlihat pada Gambar 2.

Dari hasil analisis dapat dilihat bahwa dengan adanya peningkatan konsentrasi ekstrak gambir yang diberikan pada masing-masing perlakuan menyebabkan meningkatnya nilai antioksidan. Nilai antioksidan 
tertinggi didapatkan pada perlakuan pemakaian katekin ekstrak gambir $0,4 \%$ yaitu $18,82 \%$ dan terendah pada kontrol yakni $7,91 \%$ dan berbeda sangat nyata dengan perlakuan lainnya setelah dianalisis secara statistik.

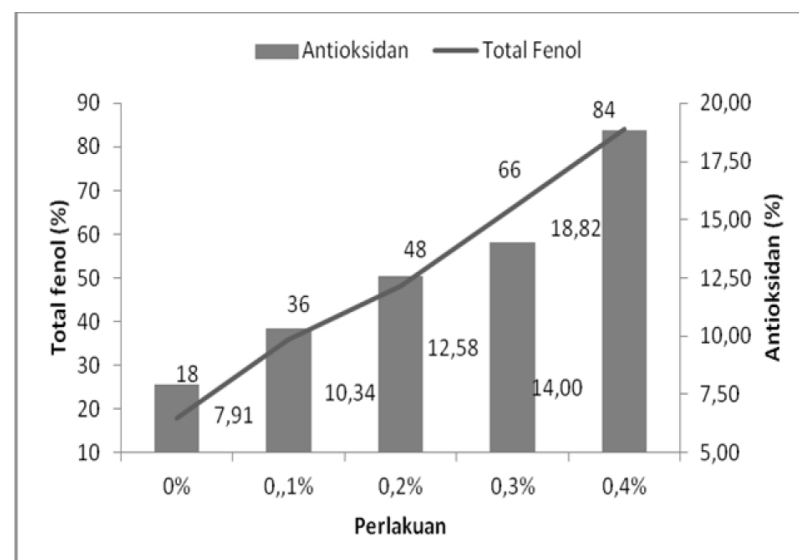

Gambar 2. Hasil analisis antioksidan dan total fenol mie basah dengan pengawet ekstrak gambir

Antioksidan merupakan senyawa yang dapat menghambat reaksi oksidasi, dengan cara mengikat radikal bebas dan molekul yang sangat reaktif, sehingga mampu mencegah terjadinya ketengikan oksidatif dari lemak. Pemberian ekstrak gambir sebagai antioksidan dapat menghambat terjadinya reaksi oksidasi dan mencegah terjadinya ketengikan pada mie basah.

Selain itu antioksidan dapat memperlambat terjadinya proses oksidasi dari lemak dan minyak, memperlambat terjadinya proses kerusakan dalam makanan, sehingga mampu memperpanjang masa pemakaian makanan, serta mencegah hilangnya kualitas sensori dan nutrisi serta berpotensi sebagai antioksidan dan antibakteri yang aman digunakan dalam pengolahan bahan pangan (Faiz et al., 2020; Kresnawaty and Zainuddin, 2009a; Oktiarni et al., 2012).

Pengujian total fenol pada ekstrak gambir menunjukkan bahwa ada perbedaan nyata penggunaan konsentrasi terhadap kandungan fenolnya. Perlakuan konsentrasi katekin ekstrak gambir 0,4\% memiliki kadar fenol yang paling tinggi senilai $84 \%$ dan berbeda nyata dengan perlakuan lainnya. Hasil total fenolik dapat dilihat pada Gambar 2.

Perlakuan penggunaan ekstrak gambir sebagai pengawet alami pada pembuatan mie basah dapat meningkatkan total fenolik pada produk (Gambar 2). Total fenol mempunyai kemampuan untuk menghambat reaksi oksidasi (antioksidan) dan menangkap radikal bebas (antiradikal) (Magdalena and Kusnadi, 2015). Dengan demikian berarti bahwa bubuk ekstrak gambir memiliki kandungan senyawa fenol yang potensial sebagai antioksidan yang bermanfaat untuk tubuh.

Senyawa fenolik dapat berfungsi sebagai antioksidan karena kemampuannya dalam menstabilkan radikal bebas yaitu dengan memberikan atom hidrogen kepada radikal bebas, sedangkan radikal yang berasal dari antioksidan senyawa fenol ini lebih stabil dari pada radikal bebasnya. Kemampuan antoksidan yang dimiliki oleh gambir serta kandungan senyawa fenolnya menjadi peran penting dalam peningkatan aktivitas antoksidan pada sampel diawetkan dengan ekstrak gambir. Kadar total fenol meningkat sesuai dengan peningkatan aktivitas antioksidannya (Kresnawaty and Zainuddin, 2009b). Katekin ekstrak gambir memiliki polifenol yang kompleks sehingga sangat potensial untuk antioksidan dan pengawet alami pada pangan ( $\mathrm{Li}$ et al., 2014; Rahmawati, Noveri; Wachyuni, 2013).

\subsection{Organoleptik}

Hasil uji organoleptik warna, aroma, rasa dan tekstur mie pangsit yang dilakukan oleh panelis berdasarkan tingkat kesukaan (uji hedonik) menunjukkan pengaruh yang berbeda nyata. Adapun hasil uji organoleptik mie basah dapat dilihat pada Gambar 3.

Uji organoleptik merupakan metode ilmiah untuk mengukur, menganalisis dan menafsirkan respon yang dirasakan dari suatu produk melalui indra manusia. Uji ini dapat dibagi ke dalam dua kategori yaitu pengujian objektif dan subjektif. Pada pengujian ini panelis berperan penting dalam pengembangan produk dengan meminimalkan resiko dalam pengambilan keputusan. Panelis dapat mengidentifikasi sifat- sifat sensori yang akan membantu untuk mendeskripsikan produk. Evaluasi nilai organoleptik berguna untuk menilai perubahan yang pada produk, untuk mengidentifikasi pengembangan, menentukan optimasi telah diperoleh, mengevaluasi dan mengamati perubahan yang terjadi selama proses atau penyimpanan, dan memberikan data yang diperlukan bagi promosi produk. Evaluasi nilai uji organoleptik juga memberikan masukan untuk penerimaan dan kesukaan dari konsumen, serta korelasi antara pengukuran sensori dan kimia atau fisik (Tarwendah, 2017).

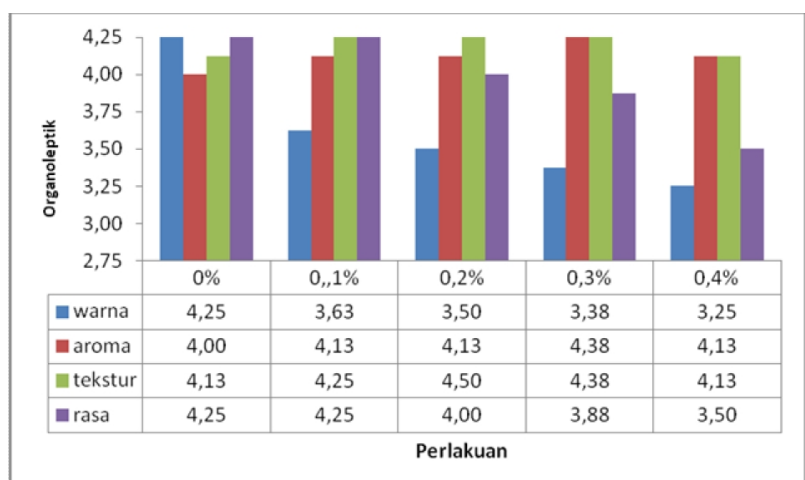

Gambar 3. Hasil analisa uji organoleptik mie basah dengan pengawet ekstrak gambir.

Dari Gambar 3 dapat dilihat bahwa penilaian uji organoleptik terhadap rasa, warna, aroma, dan tekstur oleh panelis pada mie pangsit didapatkan hasil bahwa rasa, aroma, tekstur yang paling optimal disukai adalah mie pangsit dengan pemberian ekstrak gambir $0,2 \%$, sedangkan untuk uji organoleptik warna didapatkan pada perlakuan katekin ekstrak gambir 0\% (kontrol). Namun untuk organoleptik warna, perlakuan kontrol yang menunjukkan nilai tertinggi yaitu 4,25 (sangat disukai). Hal ini memperlihatkan bahwa dengan adanya penambahan ekstrak gambir sebagai pengawet alami memberikan pengaruh nyata terhadap rata-rata organoleptik dari mie basah. 
Penambahan ekstrak gambir sebagai pengawet alami memberikan pengaruh nyata terhadap rata-rata organoleptik rasa dari mie basah. Perlakuan penambahan katekin ekstrak gambir $0,2 \%$ dan $0,3 \%$ menunjukkan tingkat kesukaan rasa tertinggi dari panelis dengan nilai 4,13 (cukup disukai), namun dengan adanya peningkatan konsentrasi ekstrak gambir yang diberikan, mengurangi nilai rasa mie basah. Bahan pangan pada umumnya tidak hanya memiliki salah satu rasa melainkan gabungan berbagai macam rasa secara terpadu.

Rasa lebih banyak melibatkan panca indera yaitu lidah, dengan lidah senyawa dapat dikenali rasanya. Semakin tinggi nilai rasa, maka tingkat kesukaan panelis terhadap rasa mie pangsit semakin besar. Penilaian mutu bahan makanan pada umumnya sangat bergantung pada beberapa faktor antara lain citarasa, warna, tekstur dan nilai gizinya, tetapi sebelum faktor lain diperhatikan secara visual faktor warna tampil lebih dulu untuk menentukan mutu bahan pangan (Tarwendah, 2017).

Winarno, 2004 dalam (Noviyanti et al., 2016) menambahkan bahwa Nilai organoleptik rasa lebih banyak melibatkan panca indera yaitu lidah, dengan lidah senyawa dapat dikenali rasanya. Semakin tinggi nilai rasa, maka tingkat kesukaan panelis terhadap rasa mie basah semakin besar. Sedangkan (Viani, 2017) organoleptik (sensori) aroma juga ditentukan oleh campuran berbagai bahan pada formula produk, seperti margarin, tepung, telur dapat menghasilkan flavor pada produk. Sedangkan tekstur suatu bahan akan mempengaruhi cita rasa yang ditimbulkan oleh bahan pangan tersebut (Noviyanti et al., 2016; Viani, 2017).

\subsection{Ketahanan simpan}

Hasil analisis kadar air dan angka lempeng total (ALT) dengan penyimpanan selama 3 hari dari mie pangsit dengan perlakuan konsentrasi ekstrak gambir terlihat pada Gambar 4. Berdasarkan hasil analisis (Gambar 4), didapatkan jumlah bakteri angka lempeng total berkisar antara $1,0 \times 10^{3} \mathrm{koloni} / \mathrm{g}$ hingga $3,7 \times 10^{6}$ koloni/g. Perlakuan tanpa pemakaian katekin ekstrak gambir (kontrol), untuk penyimpanan 3 (tiga) hari sudah tidak layak untuk dikonsumsi karena jumlah Angka Lempeng Total (ALT) sudah melebihi standar yaitu $3,7 \times 10^{6}$ koloni/g, sementara perlakuan pemberian ekstrak gambir $0,1 \%$ hanya mampu sebagai pengawet untuk penyimpanan 3 (tiga) hari dan hari ke-4 tidak layak untuk dikonsumsi.

Berdasarkan standard SNI 2987:2015 (syarat mutu mie basah) jumlah ALT yang dipersyaratkan diperbolehkan adalah harus mengandung kurang dari 1,0 x $10^{6}$ koloni $/ g$. Pada hari ke-4, perlakuan pemakaian katekin ekstrak gambir $0,2 \%, 0,3 \%$ dan $0,4 \%$ masih memenuhi standar (Badan Standardisasi Nasional, 2015). Berarti dengan perlakuan pemakaian ekstrak gambir $0,2 \%$ sudah optimal digunakan untuk menghambat pertumbuhan mikroba sampai hari ke-4 (empat), karena tidak berbeda dengan perlakuan $0,3 \%$ dan $0,4 \%$.

Dari Gambar 4 dapat dilihat bahwa ALT mie basah selama penyimpanan menunjukkan terjadinya peningkatan, dimana nilai tertinggi didapatkan pada perlakuan kontrol $(0 \%)$ dan terendah pada perlakuan pemakaian katekin ekstrak gambir $0,4 \%$ yang berbeda nyata dengan perlakuan lainnya. Dari hasil penelitian dapat dilihat bahwa adanya perlakuan pemberian ekstrak gambir berpengaruh sebagai pengawet bagi mie pangsit. Terjadinya kenaikan kadar air ini sejalan dengan bertambahnya waktu penyimpanan, diakibatkan adanya penyerapan udara di sekitarnya. Kadar air dalam bahan pangan ikut menentukan kesegaran dan daya awet bahan pangan. Kadar air yang tinggi dapat mengakibatkan mudahnya pertumbuhan bakteri, kapang, dan khamir sehingga berefek terhadap kerusakan bahan pangan (Aditya and Ariyanti, 2016).

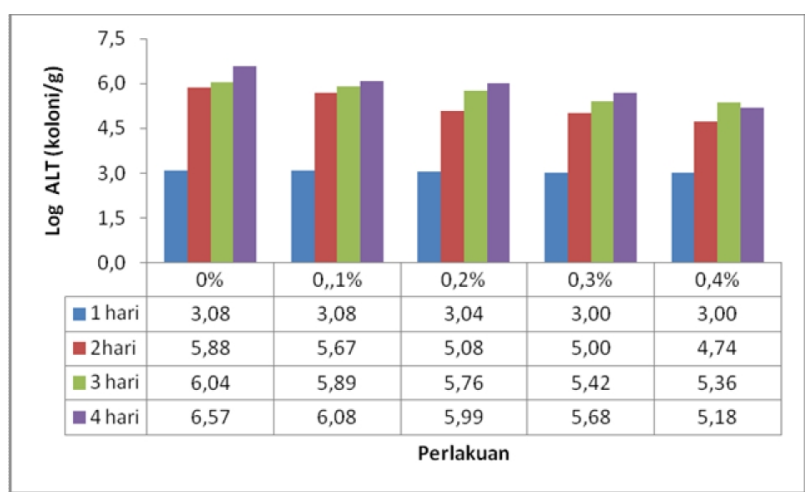

Gambar 4. Pengamatan daya simpan selama 4 hari terhadap Log Angka Lempeng Total mie basah dengan perlakuan konsentrasi ekstrak gambir sebagai pengawet alami.

Perubahan mutu produk akan menurun selama penyimpanan, suatu saat nilainya akan mendekati titik tertentu di mana kualitas yang diharapkan tersebut tidak dimiliki lagi oleh produk pangan itu. Segera setelah selesai diproduksi, perubahan mutu produk dari suatu produk adalah $100 \%$, kemudian setelah itu akan menurun selama penyimpanan, di mana laju penurunannya dapat dihitung. Penurunan mutu produk disebabkan oleh reaksi deteriorasi yang berlangsung dalam produk, karena itu penurunan nilai usable quality juga dipengaruhi oleh faktor intrinsik dan ekstrinsik. Mutu dari produk pangan dapat berupa atribut seperti tekstur, flavor, warna, penampakan khusus, nilai gizi atau berupa standar mikrobiologis (jumlah dan jenis mikroba tertentu) (Herawati, 2008; Merawati et al., 2012).

Uji Angka Lempeng Total adalah suatu metode kuantitatif yang digunakan untuk mengetahui jumlah mikroba secara keseluruhan yang ada pada suatu sampel. Metode ini menggambarkan distribusi dan kualitas mikrobiologi pada bahan pangan. Makanan yang mempunyai Aw tinggi rentan terkena kontaminasi mikroba. Aw (activity water) atau aktivitas air adalah jumlah air bebas yang tersedia dan dapat digunakan untuk pertumbuhan mikroba dalam makanan, dimana setiap mikroorganisme membutuhkan jumlah air yang berbeda untuk pertumbuhannya. Selain Aw, $\mathrm{pH}$, kandungan zat gizi bahan pangan, suhu penyimpanan dan pengolahan, ketersediaan oksigen pada makanan tersebut juga bisa menjadi penyebab tumbuhnya mikroba pada makanan. Proses $\mathrm{Aw}, \mathrm{pH}$, kandungan zat gizi bahan pangan, suhu penyimpanan dan pengolahan, 
ketersediaan oksigen pada makanan tersebut juga bisa menjadi penyebab sendiri (Danarsi and Noer, 2016; Noviyanti et al., 2016).

\section{Kesimpulan}

Perlakuan pemberian ekstrak gambir sebagai pengawet alami terhadap karakteristik mie basah, berpengaruh nyata terhadap sifat kimia (kadar air, abu, antioksidan dan total fenol) produk mie basah. Semakin tinggi konsentrasi ekstrak gambir menunjukkan peningkatan nilai kimia produk. Penggunaan kosentrasi $0,2 \%$ memberikan hasil yang optimal terhadap uji organoleptik (rasa, aroma dan tekstur) serta untuk ketahanan simpan mie basah. Pengamatan terhadap ketahanan simpan yang meliputi parameter cemaran mikroba berupa Angka Lempeng Total sampai penyimpanan 4 (empat) hari masih memenuhi standar SNI 2987:2015 (syarat mutu mie basah).

\section{Ucapan terima kasih}

Ucapan terima kasih kepada Fitriani Hidayati dan Melki Irwandi yang telah membantu selama penelitian sehingga penelitian dapat berjalan baik dan lancar.

\section{Daftar pustaka}

Aditya, M., Ariyanti, P.R., 2016. Manfaat gambir (Uncaria gambir Roxb) sebagai antioksidan. Majority 5, 129-133.

Anggraini, T., Tai, A., Yoshino, T., Itani, T., 2011. Antioxidative activity and catechin content of four kinds of Uncaria gambir extracts from West Sumatra , Indonesia. African J. Biochem. Res. 5, 33-38.

Ayu, D., Arisandy, D.A., Sepriyaningsih, 2018. Pemanfaatan jus lengkuas (Alpinia galanga L.) sebagai bahan pengawet alami dalam pembuatan mie basah dengan uji sifat organoleptik 1-6.

Badan Standardisasi Nasional, 2015. Standar Nasional Indonesia (SNI 2987:2015) Mi basah.

Badan Standardisasi Nasional, 2000. Standar Nasional Indonesia (SNI 01-3391-2000) Gambir. Badan Standardisasi Nasional, Jakarta. Indonesia.

Danarsi, C.S., Noer, E.R., 2016. Pengaruh lama penyimpanan terhadap mutu mikrobiologi makanan Pendamping air susu ibu (mp-asi) bubur instan dengan substitusi tepung ikan gabus dan tepung labu kuning. Nutr. Coll. Vol. 5, N 5, 58-63.

Enjelina, W., Rilza, Y.O., Erda, Z., 2019. Pemanfaatan kulit buah naga merah (Hylocereus polyrhizus sp.) untuk memperpanjang umur simpan mie basah. AcTion Aceh Nutr. J. 4, 63. https://doi.org/10.30867/action.v4i1.162

Faiz, M., Saad, M., Goh, H., Rajikan, R., Tuan, T.R., Baharum, S.N., Bunawan, H., 2020. Uncaria gambir (W. Hunter) Roxb: from phytochemical composition to pharmacological importance 19, 1767-1773.

Firdaus, R.A., Utami, R., Nurhartadi, E., 2015. Aplikasi ekstrak abu sabut kelapa sebagai bahan pengenyal dan pengawet alami dalam pembuatan mie basah. J. Teknol. Has. Pertan. VIII.
Herawati, 2008. Penentuan umur simpan pada produk pangan. J. Litbang Pertan. 27, 124-130.

Kailaku, S.I., Udin, F., Pandji, C., Amos, 2005. Analisis mutu dan penerimaan konsumen Terhadap permen tablet dengan formulasi konsentrasi Pengisi, pemanis dan gambir. J. Pascapanen 2, 34-40.

Kamsina, K., Firdausni, F., 2018. Pengaruh penggunaan ekstrak gambir sebagai antimikroba terhadap mutu dan ketahanan simpan cake bengkuang (Pachyrrizus erosus). J. Litbang Ind. 8, 111-117.

Kresnawaty, I., Zainuddin, A., 2009a. Aktivitas antioksidan dan antibakteri dari derivat metil ekstrak etanol daun gambir (Uncaria gambir). J. Littri 15, 145. https://doi.org/10.21082/jlittri.v15n4.2009.145151

Kresnawaty, I., Zainuddin, A., 2009b. Aktivitas antioksidan dan antibakteri dari derivat metil ekstrak etanol daun gambir (Uncaria gambir). J. Littri 15, 145-152.

Li, M., Zhu, K.X., Guo, X.N., Brijs, K., Zhou, H.M., 2014. Natural additives in wheat-based pasta and noodle products: Opportunities for enhanced nutritional and functional properties. Compr. Rev. Food Sci. Food Saf. 13, 347-357. https://doi.org/10.1111/1541-4337.12066

Magdalena, N.V., Kusnadi, J., 2015. Antibakteri dari ekstrak kasar daun gambir (Uncaria gambir var Cubadak) metode microwave-assisted extraction terhadap bakteri patogen. J. Pangan dan Agroindustri 3, 124-135.

Male, Y.T., Letsoin, L.I., Siahaya, N.A., 2017. Analisis kandungan formalin pada mie basah pada beberapa lokasi di kota Ambon. Maj. BIAM 13, 5. https://doi.org/10.29360/mb.v13i2.3530

Melia, S., Novia, D., Juliyarsi, I., 2015. Antioxidant and antimicrobial activities of gambir (Uncaria gambir Roxb) extracts and their application in rendang. Pakistan J. Nutr. 14, 938-941. https://doi.org/10.3923/pjn.2015.938.941

Merawati, D., Wibowotomo, B., Sulaeman, A., Setiawan, B., 2012. Uji organoleptik biskuit dan flake campuran tepung pisang dengan kurma sebagai suplemen bagi olahragawan. J. Teknol. Ind. Boga dan Busana 3, 7-13.

Noviyanti, Wahyuni, S., Syukri, M., 2016. Analisis penilaian organoleptik cake brownies subtitusi tepung wikau maombo. J. Sains dan Teknol. Pangan 1, 58-66. https://doi.org/http://dx.doi.org/10.1016/ S0952-1976(98)00044-X

Oktiarni, D., Ratnawati, D., Anggraini, D.Z., 2012. Pemanfaatan ekstrak kulit buah naga merah (Hylocereus polyrhizus sp.) sebagai pewarna dan pengawet alami mie basah. J. Gradien 8, 819-824.

Oktiarni, D., Ratnawati, D., Sari, B., 2013. Pemanfaatan ekstrak bunga kembang sepatu (Hibiscus rosa sinensis Linn.) sebagai pewarna alami dan pengawet alami pada mie basah. Pros. Semirata FMIPA Univ. Lampung 103-110.

Pujimulyani, D., Raharjo, S., Marsono, Y., Santoso, U., 2010. Aktivitas antioksidan dan kadar senyawa fenolik pada kunir putih. Agritech 30.

Rahmawati, Noveri; Wachyuni, A.F., 2013. Kandungan fenolik dan aktivitas antioksidan ekstrak daun gambir 
kering (Uncaria gambir (Hunter) Roxb.). J. Ind.Che.Acta 4, 1-6.

Sari, S.R., Wijaya, A., Pambayuan, R., 2019. Profil fisik ikan lele (Clarias gariepinus) asap yang diintroduksi dengan gambir (Uncaria gambir Roxb). J. FishtecH 8, 1-6. https://doi.org/10.36706/fishtech.v8i1.6623

Setyaningsih, D., Pandji, C., Perwatasari1, D.D., 2014. Kajian aktivitas antioksidan dan antimikroba fraksi dan ekstrak dari daun dan ranting jarak pagar (Jatropha curcas L.) serta study of antioxidant and antimicrobial activity of leaves and twigs extracts and fraction of Jatropha curcas. Agritech 34, 126137.
Sundari, D., Almasyhuri, Lamid, A., 2015. Pengaruh proses pemasakan terhadap protein. Media litbangkes $25,235-242$.

Tarwendah, I.P., 2017. Studi komparasi atribut sensori dan kesadaran merek produk pangan. J. Pangan dan Agroindustri 5, 66-73.

Tumbel, M., 2010. Analisis kandungan boraks dalam mie basah yang beredar di kota Makassar. J. Chem. $11,57-64$.

Viani, D.H., 2017. Karakteristik fisik dan mutu hedonik biskuit hasil substitusi tepung terigu dengan tepung pati koro pedang. Universitas Diponegoro. https://doi.org/10.1111/j.1469-7610.2010.02280.x 